\title{
SURFACE MODIFICATION OF MEDICAL TITANIUM USING CLUSTER BEAM TREATMENT
}

\author{
V. V. GRIGOROV ${ }^{1}$, I. I. SELEZNEVA ${ }^{2}$, G. A. DAVYDOVA ${ }^{3}$ \& S. M. PESTOV ${ }^{4}$ \\ ${ }^{1,2,3}$ State Scientific Centre of the Russian Federation - Leypunsky Institute for Physics and Power Engineering, \\ Joint-Stock Company, Obninsk, Russia \\ ${ }^{4}$ Obninsk Institute for Nuclear Power Engineering (OINPE), Obninsk, Kaluga, Russia
}

\begin{abstract}
One of the main approaches to improve osseous integration properties of titanium implants is to obtain micro- and nanoscale roughness of surface. This work compares the influence of various modes of cluster ion processing on topology and wet ability of titanium surface and its interaction with precursor cells of bone tissue. The advantage of this technology of surface processing, based on the action of intensive oriented cluster flows of inert gas atoms, is capability to modify surface topology at nanolevel without chemical additives. Samples after eight processing modes have been analyzed with various impact time, cathode current, solenoid current, rotation speed, and heating parameters. The impact modes have been detected, which lead to decrease in the average roughness of surface and the sizes of surface irregularities, variations of its hydrophilic and hydrophobic properties. Despite the absence of direct correlation of surface roughness and wettability with cell adhesion, the processing modes have been detected providing reliable decrease and increase in surface adhesive properties, which is attractive for development of cluster beam surface modification of titanium implants.

KEYWORDS: Surface Modification, Cluster Ion Processing, Titanium Implants, Roughness, Wettability, Cell Adhesion
\end{abstract}

Received: Jun 03, 2020; Accepted: Jun 23, 2020; Published: Jul 24, 2020; Paper Id.: IJMPERDJUN2020441

\section{INTRODUCTION}

Surgical technologies of recovery of bone tissue defects using fixing metal structures and biocompatible implants are widely applied in regenerative medicine. Improvement of biocompatibility and osseous integration of surgical bone implants as well as decrease in risk of repeated surgical intervention are highly important to improve the quality of patient care [1].

Biological activity of artificial implants is determined mainly by their surface properties, such as morphology, microstructure, and chemical composition of surface, which determine their wettability and interaction with cells and tissues. This explains significant interest to formation of surface properties providing the required effect upon various biomedical applications of materials $\left.\_2\right]$.

The main approach to improvement of osseous integration properties of implants is provision of microand nanoscale roughness resulting in increased surface adhesiveness for substrate dependent precursor cells of bone tissue and control of their differentiation in osteogenic direction [3]. The surface adhesive properties can be modified by various methods such as anodic oxidation, which increases the thickness of oxide layer, sand blasting or cathodic etching, which create conditions for adhesion and osteogenic differentiation of cells [4]. An alternative approach is application of biochemical procedures: surface coating with biopolymers such as Type I collagen [5] or 
sodium alginate [6].

Cluster beam surface processing based on the action of intensive oriented flows of cluster flows of inert gas atoms with the average energy in the range from several electron volts $(\mathrm{eV})$ to $100 \mathrm{eV}$ per atom modifies topology of material surface without addition of chemical impurities as in the case of conventional methods of surface processing [7-9]. This work is aimed at comparison of the influence of various modes of cluster ion processing on topology and wettability of titanium surface and its interaction with substrate dependent cells.

\section{MATERIALS AND METHODS}

The studies were performed with samples of titanium, grade VT1-0, in the form of discs with the thickness of $2 \mathrm{~mm}$, the diameter of $8 \mathrm{~mm}$, one of the surfaces was polished and exposed to preliminary cluster ion processing. The surface processing by cluster ion beam was carried out on cluster beam facility, Faculty of Physics, Moscow State University [10, 11]. Processing parameters were as follows: accelerating voltage $20 \mathrm{kV}$, argon flow rate via nozzle $-200 \mathrm{ml} / \mathrm{s}$, Ar dose: $5 \times 10^{16}-1 \times 10^{17}$ atom $/ \mathrm{cm}^{2}$. Samples after eight processing modes have been analyzed with various impact time, cathode current, solenoid current, rotation speed, and heating parameters. Basic mode of ion beam cleaning was as follows: voltage $\mathrm{U}_{\mathrm{A}}=1,500 \mathrm{~V}$, solenoid current Is $=2 \mathrm{~A}$, gas flow rate $(\mathrm{Ar}) \mathrm{Q}_{\mathrm{Ar}}=40 \mathrm{~cm}^{3} / \mathrm{min}$.

Table 1: Surface Processing Parameters

\begin{tabular}{|c|l|c|}
\hline Processing Mode & \multicolumn{1}{|c|}{ Preliminary Ion Beam Cleaning } & Cluster Ion Processing \\
\hline 1 & Ion beam cleaning with heating, time $1,200 \mathrm{~s}$, rotation $6 \mathrm{rpm}$ & Ar dose: $5 \times 10^{16}$ atom $/ \mathrm{cm}^{2}$ \\
\hline 2 & Ion beam cleaning w/o heating, time $1,200 \mathrm{~s}$, rotation $6 \mathrm{rpm}$ & Ar dose: $5 \times 10^{16}$ atom $/ \mathrm{cm}^{2}$ \\
\hline 3 & Ion beam cleaning w/o heating, time $1,200 \mathrm{~s} .$, w/o rotation & Ar dose: $5 \times 10^{16}$ atom $/ \mathrm{cm}^{2}$ \\
\hline 4 & Ion beam cleaning with heating, time $180 \mathrm{~s}$, w/o rotation & Ar dose: $5 \times 10^{16}$ atom $/ \mathrm{cm}^{2}$ \\
\hline 5 & Ion beam cleaning w/o heating, time $180 \mathrm{~s}$, w/o rotation & Ar dose: $1 \times 10^{17}$ atom $/ \mathrm{cm}^{2}$ \\
\hline 6 & Ion beam cleaning with heating, time $180 \mathrm{~s}$, w/o rotation & Ar dose: $1 \times 10^{17}$ atom $/ \mathrm{cm}^{2}$ \\
\hline 7 & Ion beam cleaning w/o heating, time $120 \mathrm{~s}$, w/o rotation & Ar dose: $6 \times 10^{16}$ atom $/ \mathrm{cm}^{2}$ \\
\hline 8 & Ion beam cleaning with heating, time $120 \mathrm{~s}$, w/o rotation & Ar dose: $6 \times 10^{16}$ atom $/ \mathrm{cm}^{2}$ \\
\hline
\end{tabular}

Topology of samples was analyzed using an Integra Prima (NT-MDT, Russia) scanning probe laboratory. Scanning was performed in semi-contact mode. HA_NC (ScanSens) cantilevers were used: resonant frequency $235 \mathrm{kHz}$, rounding radius not more than $10 \mathrm{~nm}$. Scanning speed was $0.5 \mathrm{~Hz}$ (lines per second). Post processing included subtraction of inclined plane. Statistical parameters were calculated using Gwyddion software.

Surface contact angles upon wetting with deionized water were measured using sitting drop method on experimental rig equipped with Newport Optics and Edmund Optics opto-mechanical devices. Five droplets of Milli-Q water $(3 \mu \mathrm{L})$ were seeded on each scaffold surface at different locations, and an average value of the contact angles and standard deviations were obtained.

Adhesive properties of the materials were analyzed using primary culture of mesenchymal stromal (stem) cells (hMSC) isolated from the rudiment of the third molar extracted by orthodontic indications [12]. The cells were grown in the content of 40 thousand cells/ $\mathrm{cm}^{2}$ in DMEM/F12 (1:1) medium supplemented with 10\% of fetal calf serum (FBS, HyClone) and $100 \mathrm{unit} / \mathrm{ml}$ penicillin/streptomycin and $2 \mathrm{mML}$ glutamine in a humidified incubator, at $37^{\circ} \mathrm{C}$ and $5 \% \mathrm{CO}_{2}$.

Cell viability was estimated by differential fluorescent staining of live and dead cells using Hoechst 33342, SYTO 9 and propidium iodide (L-7007 LIVE/DEAD BacLight Bacterial Via-bility Kit, Invitrogen). Microimages were acquired using an Axiovert 200 inverted microscope (Zeiss, Germany). 
Statistical data processing was aided by Origin 8.0 software, the error was considered as mean root square deviation from average value, reliable readings were determined using the Mann-Whitney $\mathrm{U}$ test at $\mathrm{p}<0.05$.

\section{RESULTS AND DISCUSSION}

The surface topology was analyzed using atomic force microscopy (Figure 1). Regular parameters used for characterization of roughness were as follows: Sa (average arithmetic roughness) and Sz (maximum height of surface relief determined as the difference between the heights of the highest and the lowest surface points in selected site). Minimum values of these parameters were achieved upon processing in modes 1,2 , and 3 , hence, these modes of ion beam surface modification were smoothing.

\section{Mode 1. $\mathrm{S}_{\mathrm{a}}=1.2 \mathrm{~nm} ; \mathrm{S}_{\mathrm{z}}=17.9 \mathrm{~nm}$}

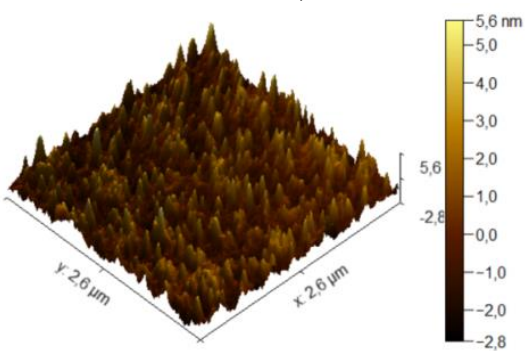

Mode 4. $\mathrm{S}_{\mathrm{a}}=6.3 \mathrm{~nm} ; \mathrm{S}_{\mathrm{z}}=70 \mathrm{~nm}$

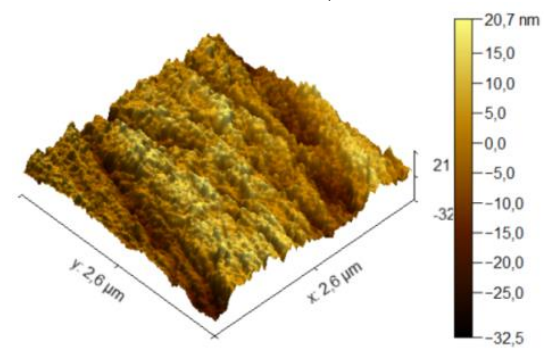

Mode 7. $\mathrm{S}_{\mathrm{a}}=5.3 \mathrm{~nm} ; \mathrm{S}_{\mathrm{z}}=53 \mathrm{~nm}$

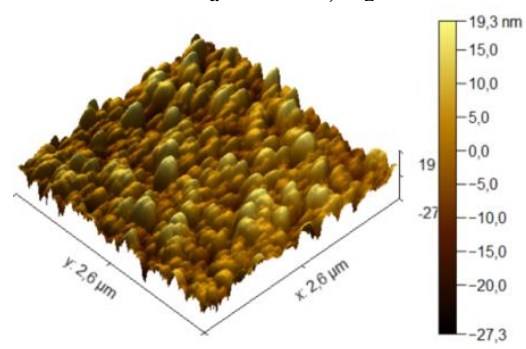

Mode $2 . \mathrm{S}_{\mathrm{a}}=1.0 \mathrm{~nm} ; \mathrm{S}_{\mathrm{z}}=14.7 \mathrm{~nm}$

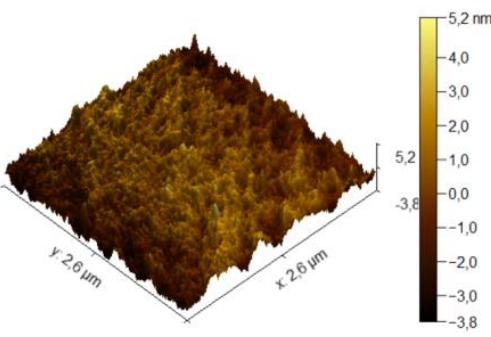

Mode 5. $\mathrm{S}_{\mathrm{a}}=3.2 \mathrm{~nm} ; \mathrm{S}_{\mathrm{z}}=36.5 \mathrm{~nm}$

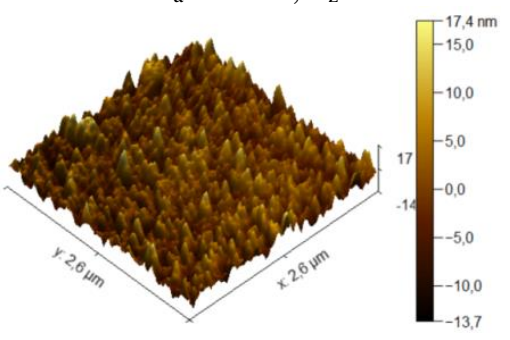

Mode $8 . \mathrm{S}_{\mathrm{a}}=5.8 \mathrm{~nm} ; \mathrm{S}_{\mathrm{Z}}=68.6 \mathrm{~nm}$

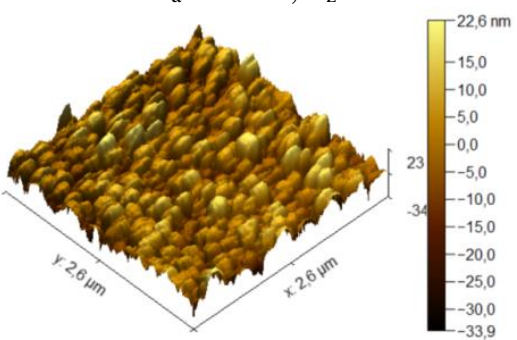

Mode 3. $\mathrm{S}_{\mathrm{a}}=1.7 \mathrm{~nm} ; \mathrm{S}_{\mathrm{z}}=19.8 \mathrm{~nm}$

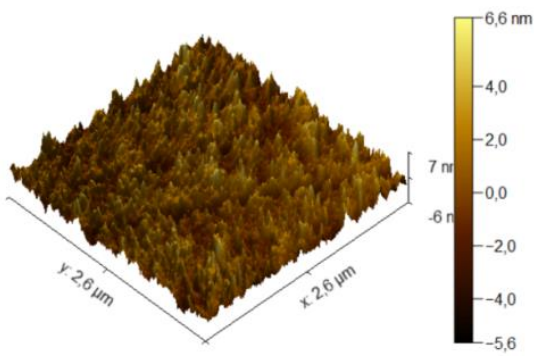

Mode 6. $\mathrm{S}_{\mathrm{a}}=4.2 \mathrm{~nm}$; $\mathrm{S}_{\mathrm{z}}=39.7 \mathrm{~nm}$

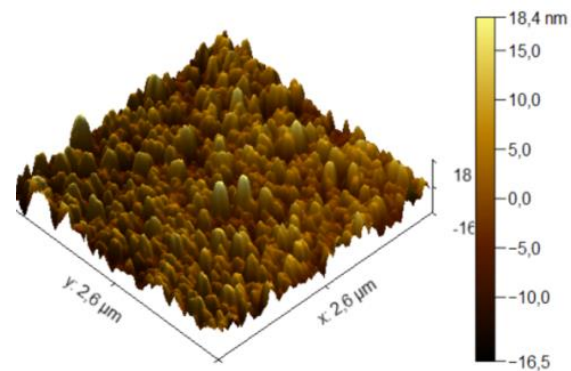

Reference. $S_{a}=5.0 \mathrm{~nm} ; S_{z}=52.5 \mathrm{~nm}$

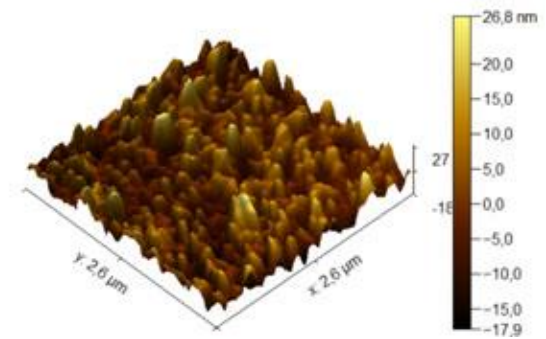

Figure 1: Topology of Titanium Surface Under Various Processing Modes. AFM Data.

Despite that the average roughness of surface upon processing in modes 4 and 8 was very close, the surface topology properties of these materials were significantly different, the average size of irregularities upon processing in mode 4 was significantly lower than in modes 7, 8 and in reference (9). The roughness and the size of irregularities of titanium surface upon processing in modes 5 and 6 were intermediate (Figure 2). 

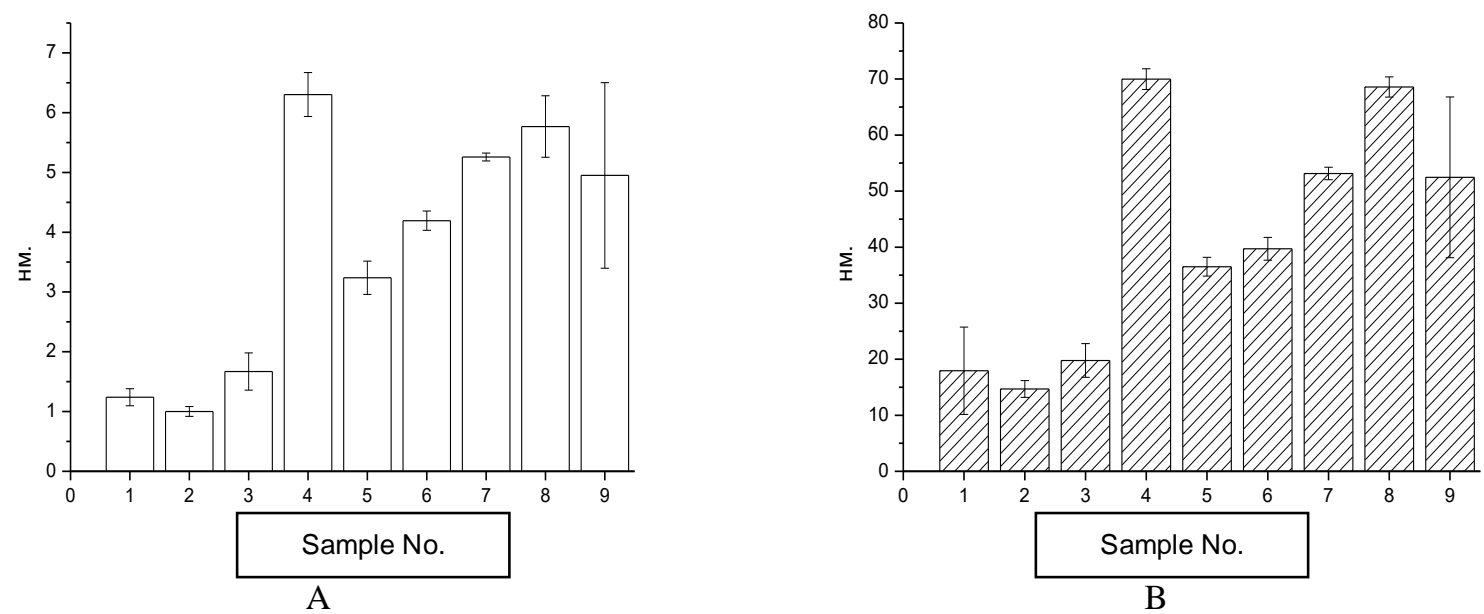

Figure 2: Average Roughness of Titanium Surface Under Various Modes of Cluster Beam Processing. Sa Average Arithmetic Roughness (A), Sz - Maximum Height of Surface Relief (B).

Analysis of surface wettability demonstrated significant increase in contact angle of material processed according to mode 4 with regard to references and other samples (Figure 3). Probably, surface hydrophobization of this sample was caused by formation of deep caverns leading to the Wenzel state, when actual contact area is significantly higher than the visible area [13].

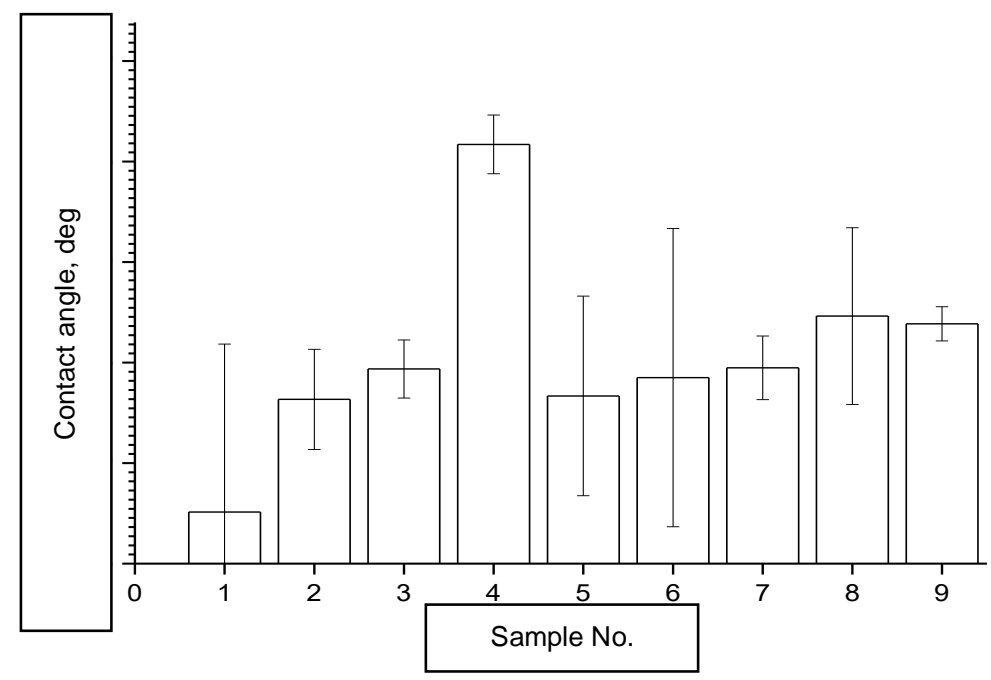

Figure 3: Contact Angles of Titanium Surface While Wetting with Deionized Water Under Various Modes of Cluster Beam Processing.

Viability and growth of substrate dependent precursor cells of bone tissue on the surface of the considered materials were analyzed by means of counting of the number of live and dead cells per unit surface area of analyzed sample. SYTO 9 fluorescent stain in test mode $\left(\lambda_{\text {excit }}=450-490 \mathrm{~nm}, \lambda_{\text {emiss }}=515-565 \mathrm{~nm}\right)$ stains into green DNA and RNA of live and dead cells. Intercalating agent, propidium iodide, in test mode $\left(\lambda_{\text {excit }}=546 \mathrm{~nm}, \lambda_{\text {emiss }}=575-640 \mathrm{~nm}\right)$ stains into red the nuclei of dead cells. Hoechst 33342 fluorescent stain in test mode ( $\left.\lambda_{\text {excit }}=355 \mathrm{~nm}, \lambda_{\text {emiss }}=460 \mathrm{~nm}\right)$ stains into blue DNA of live and dead cells (Figure 4). 


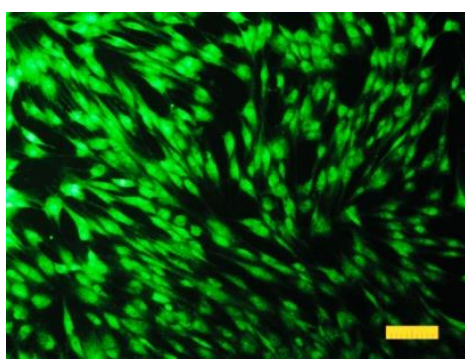

A1

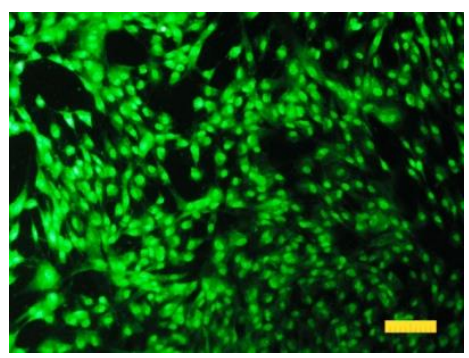

B1

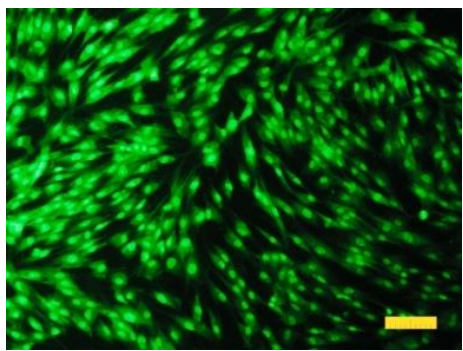

$\mathrm{C} 1$

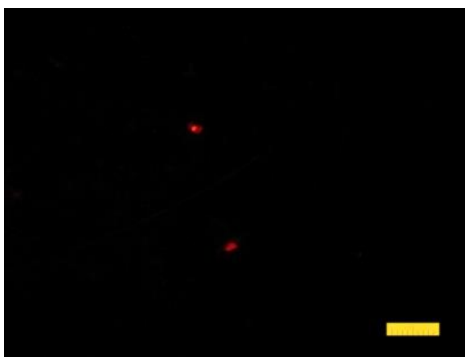

A2

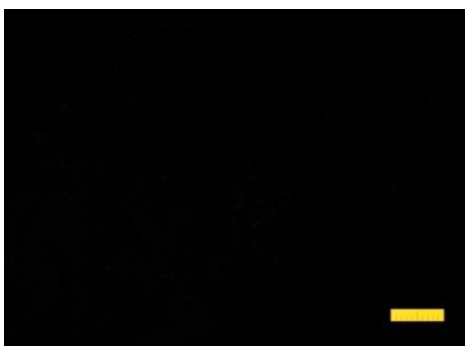

B2

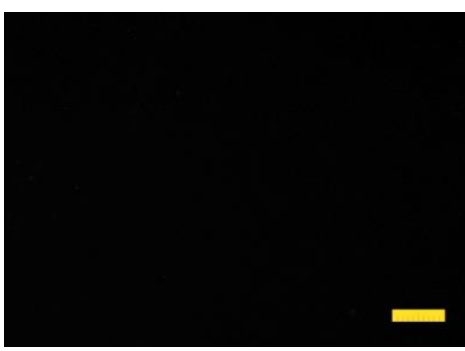

$\mathrm{C} 2$

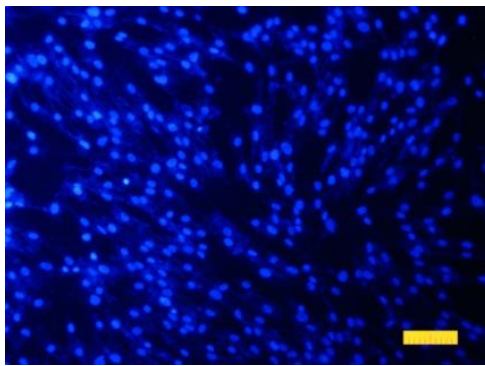

A3

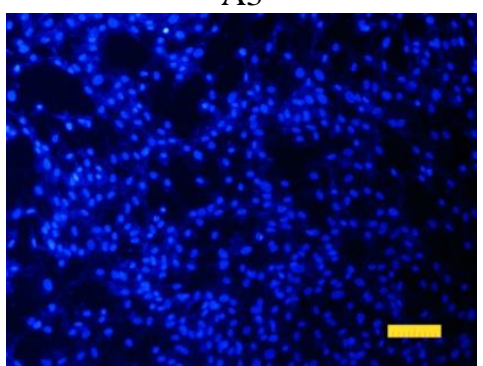

B3

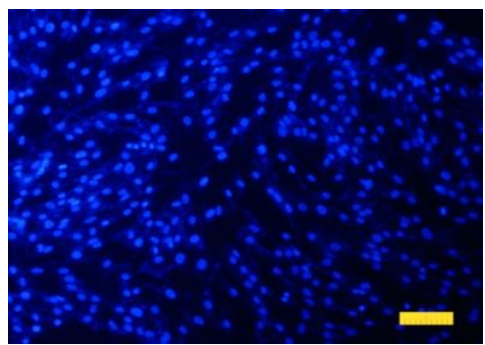

C3

Figure 4: Appearance of Cells on the Third Day After Seeding on Titanium Surface Under Various Modes of Cluster Beam Processing: A - Mode 3, B - Mode 6, C - Reference w/o Processing. Staining: SYTO 9 - (1); PI - (2), and Hoechst 33342 - (3). Scale: $100 \mu \mathrm{m}$.

It should be mentioned that the degree of cell spreading over the surfaces processed under modes 3 and 6 is lower than that under other modes and reference.

Thought, fluorescence microscopy showed that the cell viability on titanium surface under various modes of cluster beam processing revealed similar character compared with that of reference w/o processing. However, immature development of filopodial extensions observed on titanium surface under cluster beam processing in mode 6 reveals a weak bioactive potential. The titanium surface under cluster beam processing in mode 3 promotes cell adhesion and spreading and indicates better biocompatibility of scaffolds compared with other scaffold. 


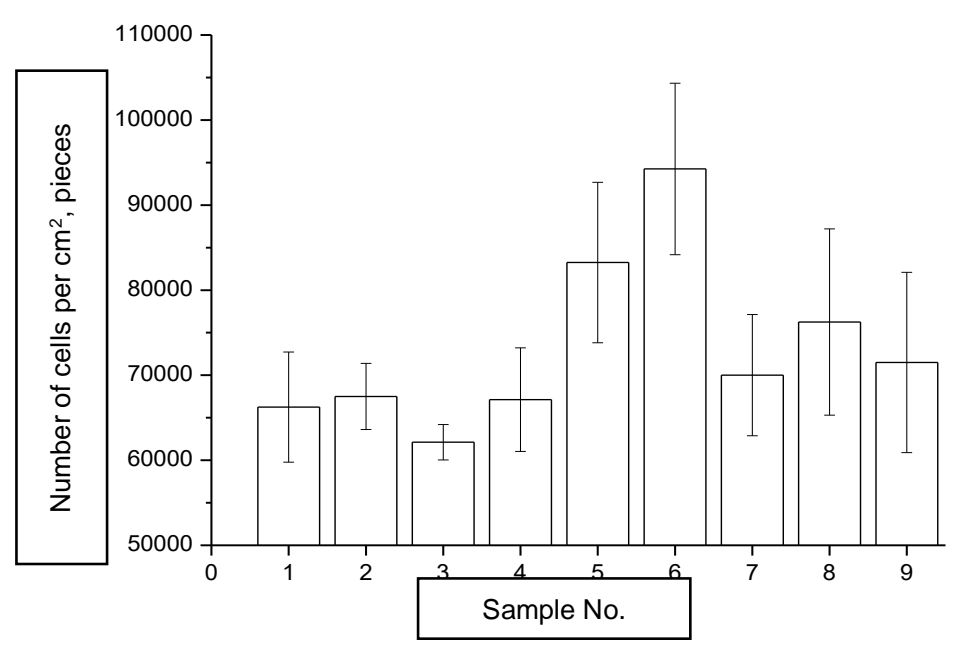

Figure 5: Cell Adhesion on Titanium Surface Under Various Modes of Cluster Beam Processing.

Table 2: Cell Counts on the First Day After Seeding on Material Surface (titanium VT1-0) Upon Various Modes of Surface Processing

\begin{tabular}{|c|c|c|c|}
\hline $\begin{array}{l}\text { Processing } \\
\text { Mode }\end{array}$ & $\begin{array}{l}\text { Density of Cell Layer (All } \\
\text { Cells), } \times 10^{3} \text { cells } / \mathrm{cm}^{2}\end{array}$ & $\begin{array}{c}\text { Amount of Dead Cells, } \\
\text { cells } / \mathrm{cm}^{2}\end{array}$ & $\begin{array}{l}\text { Density of Cell Layer, \% of } \\
\text { Reference }\end{array}$ \\
\hline 1 & $66,250 \pm 6,468$ & $500 \pm 234$ & 92.7 \\
\hline 2 & $67,500 \pm 3,888$ & $625 \pm 198$ & 94.4 \\
\hline 3 & $62,125 \pm 2,078$ & $375 \pm 250$ & 86.9 \\
\hline 4 & $67,125 \pm 6,094$ & $125 \pm 125$ & 93.9 \\
\hline 5 & $83,250 \pm 9,436$ & $250 \pm 153$ & 116.4 \\
\hline 6 & $94,250 \pm 10,077$ & $125 \pm 125$ & 131.8 \\
\hline 7 & $70,000 \pm 7,126$ & $375 \pm 250$ & 97.9 \\
\hline 8 & $76,250 \pm 10,946$ & $625 \pm 342$ & 106.6 \\
\hline Reference (9) & $71,500 \pm 10,604$ & $375 \pm 250$ & 100 \\
\hline
\end{tabular}

\section{CONCLUSIONS}

Therefore, comparison of the influence of various modes of cluster ion processing on topology and wettability of titanium surface and its interaction with substrate dependent cells did not reveal direct correlation of surface roughness and wettability with cell adhesion under various modes of surface processing. However, capability to achieve both decrease in surface adhesiveness (mode 3) and its significant increase (mode 6) in comparison with reference by variation of parameters of cluster beam processing is attractive for development of cluster beam modification of surface of titanium implants.

\section{ACKNOWLEDGMENTS}

This work was supported by the Ministry of Science and Higher Education of the Russian Federation (Unique PNIER identifier: RFMEFI57918X0157, Federal grant No. 075-11-2018-173, dated November 30, 2018).

\section{REFERENCES}

1. Staruch, R.M.P., Griffin, M.F., Butler, P.E.M. Nanoscale Surface Modifications of Orthopaedic Implants: State of the Art and Perspectives. Open Orthop J. 10 (2016) 920-938.

2. Gittens, R.A., Scheideler, L., Rupp, F., Hyzy, S.L., Geis-Gerstorfer, J., Schwartz, Z., Boyan, B.D. A review on the wettability of dental implant surfaces II: biological and clinical aspects. Acta Biomater. 10 (2014) 2907-2918. 
3. Suresh, Ganzi, et al. "Electro chemical behaviour of lensTM deposited Co-Cr-W alloy for bio-medical applications." Int. J. Mech. Prod. Eng. Res. Dev 2018 (2018): 41-52.

4. Zhao, G., Zinger, O., Schwartz, Z., Wieland, M., Landolt, D., Boyan, B. Osteoblast-like cells are sensitive to submicron-scale surface structure. Clin. Oral Implants Res. 17 (2006) 258-264.

5. Kalita, V.I. Fizika i khimiya formirovaniya bioinertnykh i bioaktivnykh poverkhnostei na implantatakh [Physics and chemistry of formation of bioinert and bioactive surfaces on implants]. Fizika i khimiya obrabotki materialov 5 (2000) $28-45$.

6. Morra, M., Cassinelli, C., Cascardo, G., Bollati, D., Baena, R. Gene expression of markers of osteogenic differentiation of human mesenchymal cells on collagen I-modified microrough titanium surfaces. J. Biomed. Mater. Res. A. 96 (2011) $449-455$.

7. Cagan, Suleyman Cinar, and Berat Baris Buldum. "Investigation of the effect of minimum quantity lubrication (MQL) on the machining of titanium and its alloys a review." Int. J. Mech. Prod. Eng. Res. Dev. 7 (2017): 453-462.

8. Pullisaar, H., Tiainen, H., Landin, M.A., Lyngstadaas, S.P., Haugen, H.J., Reseland, J.E., Lyngstadaas, S.P., Haugen, H.J., Reseland, J.E., Ostrup, E. Enhanced in vitro osteoblast differentiation on TiO2 scaffold coated with alginate hydrogel containing simvastatin. J. Tissue Eng. 4 (2013) 204.

9. Yamada, I. Historical milestones and future prospects of cluster ion beam technology. Applied Surface Science 310 (2014) $77-$ 88.

10. Aziz, Wisam, Raad Sabry, and Ahmed Sadek Ali. "Preparation and Characterization of Tin Oxide Nanoparticles Using (PLALl)." International Journal of Industrial Engineering \& Technology (IJIET) ISSN (P) (2016): 2277-4769.

11. Yamada, I. Progress and applications of cluster ion beam technology. Current Opinion in Solid State and Materials Science 19 (2015) 12-18.

12. Kirkpatrick, A., Kirkpatrick, S., Walsh, M., Chau, S., Mack, M., Harrison, S., Svrluga, R., Khoury, J. Investigation of accelerated neutral atom beams created from gas cluster ion beams. Nucl. Instr. and Meth B 307 (2013) 281-289.

13. Zeid, Efabo, and A. Gaber. "Mechanical Properties and Precipitation Behavior As A Function of." Science and Engineering (IJMMSE) 2.4 (2012): 11-20.

14. Andreev, A.A., Chernysh, V.S., Ermakov, Yu.A., Ieshkin, A.E. Design and investigation of gas cluster ion accelerator. Vacuum 91 (2013) 47-53.

15. Chernysh, V.S., Ieshkin, A.E., Ermakov, Y.A. The new mechanism of sputtering with cluster ion beams. Appl. Surf. Sci. 326 (2015) 285-288.

16. Khoury, J., Kirkpatrick, S.R., Shashkov, D., Selezneva, I., Ermakov, A., Mikheev, A., Pestov, S., Lazov, M., Smolkov, A., Tarassov, V. Surface bioactivation of PEEK by neutral atom beam technology. Bioactive Materials 4 (2019) 132-141.

17. Wenzel, R.N. Resistance of solid surfaces to wetting by water. Ind. Eng. Chem. 28 (1936) 988-994. 

